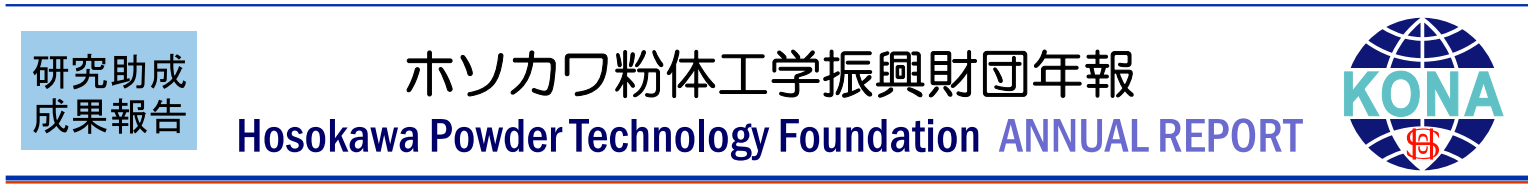

16123

\title{
新規金属潜熱蓄熱粉システムの開発 \\ Development of New Metal Latent Heat Storage System
}

研究代表者 Research leader：米澤 徹 Tetsu YONEZAWA

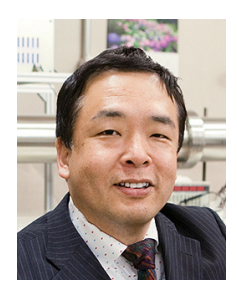

北海道大学大学院工学研究院 教授

Faculty of Engineering, Hokkaido University, Professor

E-mail: tetsu@eng.hokudai.ac.jp

抄 録

熱マネジメントを可能とする金属ナノ粒子潜熱蓄熱粉システムを構築する研究を行う．既存の有機 材料では応用が困難な中温度領域 $\left(200^{\circ} \mathrm{C} \sim 400^{\circ} \mathrm{C}\right)$ を目指し, 高熱伝導率で抜熱効果が優れる低 融点金属や合金のナノ粒子を潜熱蓄熱材として利用する。例えば，マフラーの熱をエンジン部に輸 送するなどの，PCM を用いた熱輸送システムへと展開することを目標としている，具体的には， 金属酸化物と金属をべースとしたコアシェル型コンポジットナノ粉体を作製し，それを液中に分散 させて用いる，本研究では，スズナノ粒子をシリカなどでコーティングしたコアシェル型ナノコン ポジットを作製し, その微細構造を検証し, 熱挙動について検討を重ねた。 そして, 得られたコア シェル型ナノコンポジットは, 高温時のスズの融合・焼結を防ぐことが可能で, 溶解凝固繰り返し 100 サイクルまで顕著な変化を見せなかった．

\begin{abstract}
We report here the preparation of metal/metal oxide core-shell particles as phase-change materials (PCM) which work as a latent heat storage system. In this study, silica-coated tin nanoparticles have been prepared. Sn nanoparticles were distributed inside for enhancing the thermal cyclic stability. After immersing the solution of Sn precursor, silica matrix was treated by hydrogen thermal reduction to obtain $\mathrm{Sn} @ p-\mathrm{SiO}_{2}$ nanoparticles. The porous silica matrix effectively prevented the coalescence or sintering of the $\mathrm{Sn}$ nanoparticles. The product did not show considerable changes in melting behavior up to 100th cycle of a freeze-melt cycle test.
\end{abstract}

\section{研究背景と目的}

排熱として廃棄される未利用エネルギーを有 効活用するために，既存の有機材料では利用す ることが難しい中温度領域，具体的には $200^{\circ} \mathrm{C}$ $\sim 400^{\circ} \mathrm{C}$ 程度の領域の熱の活用をめざして, 高
い伝導率をもち，優れた抜熱効果も期待できる 低融点金属ならびに合金ナノ粒子の潜熱蓄熱材 への応用について検討を行う。

低融点金属は，このような中温度領域に用い られる蓄熱・熱マネジメントのための PCM (Phase Change Materials) として非常に有望で 
ある（Hyun D.C. et al., 2014）。つまり，(1)金属 は蓄熱媒体として高い熱伝導率を持つため, 迅 速な抜熱を行うことができる；金属の高体積密 度は小さい蓄熱媒体の形成を可能とする；とい う特徵を有する材料である（Pielichowska and Pielichowski, 2014; Nomura T. et al., 2015)，そこ で，この PCM としての金属をナノ粒子化し， 液体媒体に分散させて用いることができれば, 蓄熱ナノ流体として, 優れた熱伝達媒体として 用いることが可能であると考えられる（図 1).

しかしながら, 蓄熱・放熱の操作中にこの $\mathrm{PCM}$ 金属が液相・固相と変化することから, 粒子が焼結されることによってコロイド状態と してのナノ流体の安定性が低下し，蓄熱サイク ルを悪くしてしまう。そのために，個々のナノ 粒子が常に独立して分散している必要がある。 そのためには，金属ナノ粒子の外部に不活性な 固体シェル層を形成することが必要である。ま た, Bi ナノ粒子を高融点金属である銀マトリッ クスや耐熱ポリマーであるポリイミドマトリッ クスに包埋した例も報告されている。

そこで本研究では, スズを PCM 材料として 用い，ポーラスシリカを用いてスズナノ粒子の 独立性を担保してナノ流体を得ることを試みた。 この手法は，様々な金属を用いることができる 可能性が高い汎用的な手法である。また，ポー ラスシリカは表面修飾が容易で親水性・疎水性 両方の溶媒への分散が簡単にできることが期待 される，本研究ではスズナノ粒子の合成は化学 還元法によって行うこととした。我々はスズの 液相化学還元法による合成についても報告して いるが（Shirai H. et al., 2016），本研究では水素 還元法によって包埋させることを検討した．

\section{研 究 方 法}

\section{1. 原料}

金属ナノ粒子として，スズナノ粒子を用いる こととした，スズナノ粒子は化学 (水素) 還元 法によって合成した。また，コーティングする 金属酸化物としてポーラスシリカを作成して用 いた。

スズ源として無水塩化スズ（II）（純正化学） を用いた。アンモニア水，1-プロパノール（純 正化学)，エタノールは精製せずに用いた。保 護界面活性剤としてへキサデシルトリメチルア ンモニウムブロミド（CTAB，東京化成）を使 用した、コーティングのためのシリカ原料はテ トラエチルオルトシリケート (TEOS, 和光純薬) を用いた。水は超純水（オルガノ）を使用した。

\section{2. ナノ粒子の合成}

ポーラスシリカは文献の方法に従って合成し た（Yu Q. et al., 2011）。簡潔に説明する. $4.8 \mathrm{~g}$ の $\mathrm{CTAB}$ を $160 \mathrm{~cm}^{3}$ のエタノールと $240 \mathrm{~cm}^{3}$ の 水との混合溶媒に溶解した。続いて, $3.2 \mathrm{~cm}^{3}$ のアンモニア水溶液および $6.4 \mathrm{~cm}^{3}$ の TEOS を この CTAB 界面活性剂溶液に添加した。この 混合反応溶液を 4 時間攪拌しシリカ球を得た. 次に，得られたポーラスシリカ球は遠心装置を 用いて毎分 8000 回転で 10 分間の遠心分離を行 い，上澄みを取り除いた後，1-プロパノール で洗浄した。 得られた粉末は 1 晚真空乾燥した。

次にこのシリカにスズを包埋させた。 この典 型例について以下に述べる。上記のように調製 したポーラスシリカ $0.1 \mathrm{~g}$ を水に分散させて, さらに適切量の塩化スズ (II) を加えて 30 分

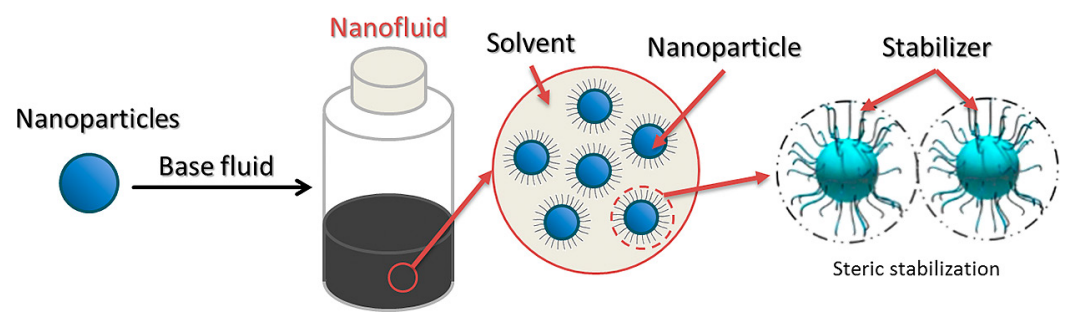

Fig. 1 Schematic illustration of nanofluid containing phase change material (PCM) nanoparticles. 
間超音波処理した。その後，6時間攪拌した。 このようにして合成したスズ前駆体を担持した ポーラスシリカを遠心分離機を用いて毎分 10000 回転で遠心分離して回収し, 水と1-プ ロパノールで洗浄した後, 真空乾燥した.

得られた白色の乾燥スズ担持ポーラスシリカ 粉末をアルミナボートに写し，管状炉中で $3 \%$ 水素（窒素希䣋）気流下で $260^{\circ} \mathrm{C} \sim 550^{\circ} \mathrm{C}$ の 温度で 6 時間還元操作をした，最大収率は $63 \%$ 程度であった。

\section{3. 解析}

ナノ粒子の形，大きさ，金属・金属酸化物の 構造については透過型電子顕微鏡（TEM, JEOL JEM-2000CX, 加速電圧 $200 \mathrm{kV}$ ）を用い て観察した。結晶構造については, X 線回折(リ ガク・ミニフレックス II）を用いて解析を行っ た、結晶子サイズについてはXRDのピークか らシェラーの式を用いて算出した，X線光電子 分光（XPS，JEOL JPS-9200）を用いてスズの電 子状態やシリカの厚みなどを検討した. 熱分析・ DTA（TG-DTA カーブ）は島津 DTG-60Hを用 いてアルミナパンを試料台として用いて検討し た。還元性ガスを用いるときには，TG-DTA 装 置の検出部に $3 \%$ 水素ガス（窒素希釈）を毎分 $100 \mathrm{~cm}^{3}$ 流した，加熱速度は毎分 $5^{\circ} \mathrm{C}$ であった。 融解一凝固サイクル試験は, 示差走査熱量計 (DSC，TA インスッルメンツ DSC2500 熱量計) を用いて測定した。測定環境は，99.995\% 窒素 ガスを毎分 $50 \mathrm{~cm}^{3}$ 流して測定した。

\section{研 究成 果}

\section{1. $\mathrm{Sn} @ p-\mathrm{SiO}_{2}$ ナノ粒子の合成}

調製直後のポーラスシリカ粉末のXRD パ ターンはアモルファス構造を示していた。 $20^{\circ}$ から $30^{\circ}$ にみられる幅広いピークはこのアモル ファスシリカ構造を示している（図2）.

透過型電子顕微鏡（TEM）で得られたナノ 粒子の構造を観察した結果, ポーラスシリカの 大きさは $400 \mathrm{~nm}$ 程度の直径を有していた。 久

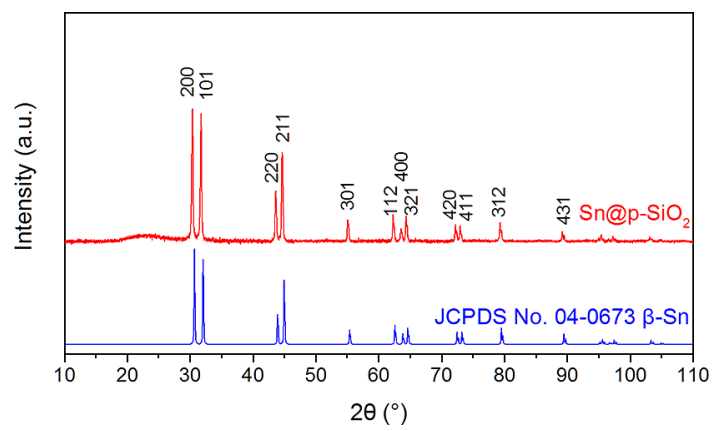

Fig. 2 X-ray diffractogram (XRD) of $\mathrm{Sn} @ p-\mathrm{SiO}_{2}$ nanoparticles. Broad peak between $20^{\circ}$ to $3^{\circ}$ indicate amorphous $\mathrm{SiO}_{2}$. Sharp peaks are corresponding to those of $\beta$-Sn.

ズを 3\% 水素雲囲気下で還元したところ, ポー ラスシリカのサイズに大きな変化は見られな かったが，ポーラスシリカ内部に高いコントラ ストを示す黒い点が見られた。この部分は金属 スズである。この TEM 像から，ポーラスシリ カ内にスズが取り达まれていることが示唆され る。この TEM 像からスズナノ粒子の粒子径は 約 $30 \mathrm{~nm}$ 程度であった，スズ含有ポーラスシリ カの XRD パターンには金属スズのピークが見 られた。このスズのピークから予想される結晶 子サイズは $6.5 \mathrm{~nm}$ よりも小さい.

また，制限視野電子線回折（SAED）による 局所の結晶構造解析結果は, 正方晶スズの格子 面に起因する回折スポットが見られ，XRDの 結果ともよく一致して抢り, 金属スズ結晶が生 成していることが明確となった。 シリカを $\mathrm{HF}$ で溶解させてスズナノ粒子を取り出すことを試 みたがうまくは行かなかった。

このスズ・ポーラスシリカコアシェルナノ粒 子の XPS 解析を行った（図 3). 表面からデプ スプロファイルを深さ $210 \mathrm{~nm}$ まで行った。 ア ルゴンエッチングの深さが深くなるほど Sn の 検出量が相対的に増大していったここれにより， スズ・ポーラスシリカコアシェルナノ粒子の形 成が確認された。

\section{2. $\mathrm{Sn} @ p-\mathrm{SiO}_{2}$ ナノ粒子の熱サイクル試験}

示差走査熱量計（DSC）を用いて, 得られた 


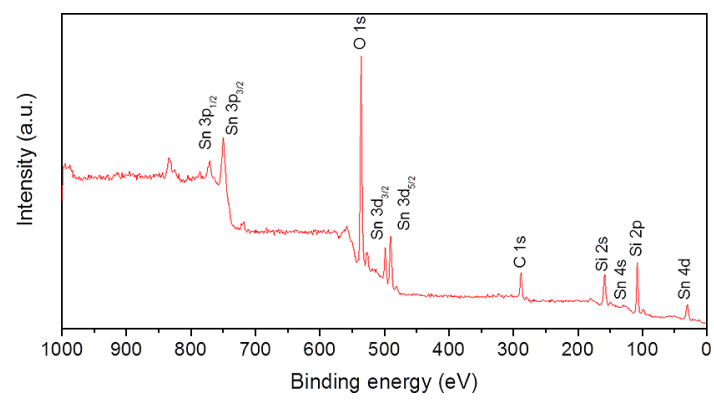

Fig. 3 Wide-scan x-ray photo-spectrum (XPS) of Sn@ $p-\mathrm{SiO}_{2}$ nanoparticles. We can easily find clear peaks corresponding to $\mathrm{Sn}$ and $\mathrm{Si}$.

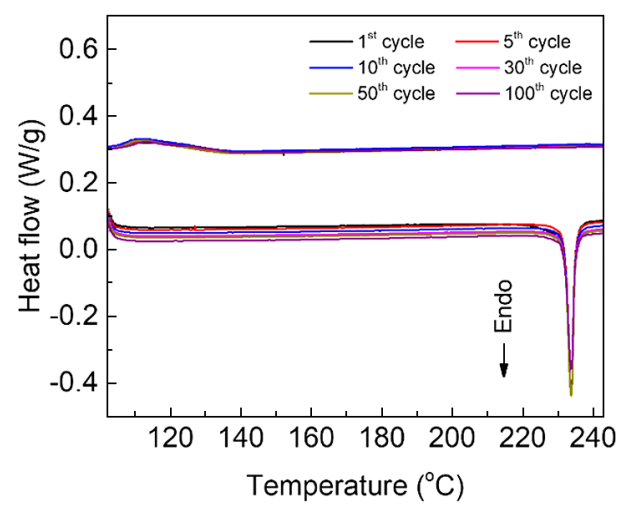

Fig. 4 DSC results for 100 melt-freeze cycles for $\mathrm{Sn} @ p-\mathrm{SiO}_{2}$ nanoparticles.

$\mathrm{Sn} @ p-\mathrm{SiO}_{2}$ ナノ粒子の $\mathrm{PCM}$ としての性能を検 査するために，DSCを用いた熱サイクル試験 を行った。

$\mathrm{SiO}_{2}$ 内に存在する $\mathrm{Sn}$ ナノ粒子の融解による 吸熱ピークが約 $230^{\circ} \mathrm{C}$ 付近に観察される (図 4). また, 冷却中には, $105^{\circ} \mathrm{C}-140^{\circ} \mathrm{C}$ 領域に発熱ピー クが観察され，これは溶けたスズの凝固による ものと理解される。バルクのスズでは, $130^{\circ} \mathrm{C}$, $143^{\circ} \mathrm{C}, 161^{\circ} \mathrm{C}$ 付近にピークが観察されること から，ナノ粒子化することによってナノ粒子の 凝固の挙動がバルクとはやや異なることが示唆 された。

このサイクルテストによって, 100 サイクル すべてにおいて同じ温度で吸熱ピークが存在し
ている。これは、シリカ中での $\mathrm{Sn}$ ナノ粒子の 安定性が高いことを示唆している。第 1 サイク ルから第 2 サイクルにかけて融解エンタルピー が減少するが，その後はほぼ一定の值を保って いることもこの図から明らかとなった。

\section{結} 論

本研究では，相変化するスズナノ粒子をポー ラスシリカ内に閉じ込めたコアシェルナノコン ポジットを一般的な原料を用いて簡便に合成可 能であることを示した。得られた $\mathrm{Sn} @ p-\mathrm{SiO}_{2}$ ナノ粒子は 100 サイクルの融解凝固繰り返し試 験でも安定に同じ温度での融解を繰り返すこと が分かった。これは， $p-\mathrm{SiO}_{2}$ でのスズの融解が このシェル構造にダメージを与えず，独立した 状態での融解凝固を可能にしているからである と考えられる。

\section{参考文献}

Hyun D.C., Levinson N.S., Jeong U., Xia Y., Emerging applications of phase-change materials (PCMs): Teaching an old dog new tricks, Angew. Chem. Int. Ed., 53 (2014) 3780-3795. DOI: 10.1002/anie.201305201

Nomura T., Zhu C., Sheng N., Saito G., Akiyama T., Microencapsulation of metal-based phase change material for high-temperature thermal energy storage, Sci. Rep. 5 (2015) 9117. DOI: 10.1038/srep09117

Pielichowska K., Pielichowski K., Phase change materials for thermal energy storage, Prog. Mater. Sci. 65 (2014) $67-$ 123. DOI: $10.1016 /$ j.pmatsci.2014.03.005

Shirai H., Nguyen M.T., Ishida Y., Yonezawa T., A new approach for additive-free room temperature sintering of conductive patterns using polymer-stabilized $\mathrm{Sn}$ nanoparticles, Journal of Materials Chemistry C, 4 (2016) 2228-2234. DOI: 10.1039/C6TC00161K

Yu Q., Wang P., Hu S., Hui J., Zhuang J., Wang X., Hydrothermal synthesis of hollow silica spheres under acidic conditions, Langmuir, 27 (2011) 7185-7191. DOI: $10.1021 / \mathrm{la} 200719 \mathrm{~g}$ 


\section{外部発表成果}

\section{論文発表}

1. Zhu S., Nguyen M.T., Fumoto K., Kanie K., Muramatsu A., Yonezawa T., Sn nanoparticles confined in porous silica spheres for enhanced thermal cyclic stability, ACS Appl. Nano Mater., 1 (2018) 4073-4082. DOI: 10.1021/acsanm. $8 b 00698$

\section{口頭・ポスター発表}

1. Shilei Zhu, Mai Thanh Nguyen, Tetsu Yonezawa, "Synthesis of Sn nanoparticles confined within mesoporous silica nanosphere", 日本金属学会 2017 年秋期（第 161 回）講演大会（6-8,
Sept. 2017) P68.

2. Shilei Zhu, Mai Thanh Nguyen, Tetsu Yonezawa, "Synthesis of Sn nanoparticles embedded in $\mathrm{SiO}_{2}$ ”, 化学系学協会北海道支部 2018 年冬季 研究発表会 (Sapporo, 16-17, Jan. 2018) $1 \mathrm{C} 08$.

3. Shilei Zhu, Mai Thanh Nguyen, Tetsu Yonezawa, "Synthesis of InSn alloy nanoparticles for thermal storage”, 平成 30 年度日本金属学会 · 日本鉄鋼協会両北海道支部合同サマーセッ ション（Sapporo, July 13, 2018） No. 4.

4. Shilei Zhu, Mai Thanh Nguyen, Tetsu Yonezawa, "Facile synthesis of $\mathrm{Al}_{2} \mathrm{O}_{3}$ coated $\mathrm{Sn}$ for reversible thermal energy", 平成 30 年度 日本 鉄鋼協会・日本金属学会両支部合同冬季講 演大会（10-11, Jan. 2019）B20. 